\title{
Challenging Issues in Translating Conversational Implicature from English into Arabic
}

\author{
Muna Ahmad Al-Shawi (Corresponding author) \\ Ministry of Education and Higher Education, Qatar \\ Tengku Sepora Tengku Mahadi \\ School of Languages, Literacies \& Translation, Universiti Sains Malaysia, Malaysia
}

Received: 21-02-2017

doi:10.7575/aiac.ijclts.v.5n.2p.65
Accepted: 26-04-2017

Published: 30-04-2017

\begin{abstract}
Conversational implicature is known as an additional meaning indirectly implicated by saying another thing. In this sense, the aim of this paper is to discuss the problems of translating conversational implicature from English into Arabic. the data is selected from two English literary works; Lord of the Flies and Nineteen Eighty-Four along with their Arabic translation. Two theoretical frameworks are implemented for the descriptive analysis of the selected texts, Skopos approach and Grice's Implicature. These two theories, along with their rules, provide appropriate standards to measure the accuracy of such translations from English language into Arabic. The analyses reveal that the translators encountered problems and obstacles during the translation into Arabic for several reasons, including linguistic, social and cultural. therefore, the translators followed different approaches and techniques to achieve consistent coherent Arabic text, equivalent to that of the original. In conclusion, the study illustrates that both theories are successful and applicable at varying levels, in translating conversational implicature from English into Arabic. Nevertheless, Grice's approach is more successful in translating the conversational imlicatures within the framework of this study. Accordingly, this study answers all the designed questions.
\end{abstract}

Keywords: Conversational Implcature, Skopos, Cooperative principles (CP), Grice's Maxims, Translation, Macro analysis, Micro- analysis.

\section{Introduction}

Meaning seems to be the most obvious feature of language and the most obscure aspect to study. These features seem obvious because people use language to communicate with each other and to transfer "what they mean" efficiently and effectively. However, the steps in creating understanding sometimes are obscure because a word may imply more than one meaning. The intended meaning of a given word or a phrase can be understood precisely when it is a part of the composition of the sentence or text because a communication is not only using words or idioms that stand for beliefs, events or feelings but the way of using them in a particular situation (Guessabi 2013:225). Therefore, the gist of a particular word or a phrase may not portray the complete picture of a text; there are several factors that have influence in determining intended meanings such as the way phrases or words are used to transport information in context, i.e., the contextual propositions in which the sentence is used (Lyons, 1995:588). Thus, the users of a language may communicate more information than what they utter by using the lexical items of that language. This extra meaning undergoes to several pragmatic inferences which, sometimes, are not bound to any particular words or phrases in utterances. Rather, they appear from contextual factors that are known as implicit meanings (Odgen and Richards: 1923). Though, the technical term of the implicit meaning in the pragmatics subfield of linguistics is called implicature, which refers "to what is suggested in an utterance, even though neither are expressed or implied by that utterance" (Gazdar 1979:49).

Whereas, the implicature that is associated with conversations is an additional meaning and known as conversational implicature, which is predicted from the nonconventional structure/pragmatic inference as shown in the following example (Grice, 1975):

Ellen: Will you go to Tom's party?

Barb: I have to clean the house and cook for tomorrow.

Obviously, in this short conversation that what the sentence means differs from what the speaker means.

In order to reach a better understanding of the implicature in the conversations, the interpreter (translator) tries hard to get the intended meaning which is equivalent to the original text in terms of quality and quantity. Therefore, translators may differ in the approach to transfer the intended meaning in source language accurately with minimal loss of the meaning to the target language.

This means that the surface meaning of the sentence/s and the hidden meaning (the implicature) are two different concepts. If was a literal translation does not reflect the deliberate meaning, then the translator turns to dispose another way of translation. Hence, another problem may appear where t here is no guarantee that the implicature has equivalent 
in the target language. Thus, conversational implicature poses a dilemma for the interpreter/ translator. The question here is what really to translate? the apparent meaning or the hidden meaning of the sentence (its implicature)? Therefore, this study focuses on the problematic issues in the translation of implicature in everyday conversations between people, which to our knowledge has not been addressed by the researchers yet, especially when moving from English to Arabic.

\section{The Problem}

Language is not as smooth or direct as it seems. There are many ways in which misunderstanding may arise, especially in cases in which the speakers' words mean one thing, while s/he is trying to transfer another or additional meaning. Hence, implied meaning is purely associated with the non-literal meanings of a word.

Accordingly, choosing the most convenient way to translate conversational implicature is considered a central problem in translation. What it is really to translate, the meaning of the sentence or its implicature? Accordingly, conversational implicature is a serious issue in the translation. Therefore, the aim of this study is to discuss the problems of translation conversational implicature from English to Arabic. Although there are other problems that need further study and deep analysis.

to investigate what happens to the original texts while translating conversational implicatures. The literature review shows that such a problem has not been addressed as intensely as it should be, specifically in moving from English to Arabic. Our target will be focused on the problems of translating conversational implicature from English into Arabic.

\section{The Objectives}

The objectives of this study are to:

1. Test the effects of the linguistic and cultural differences between English and Arabic on the adequacy of the translation through Skopos theory

2. Investigate the approach/s that the translators followed to overcome the problems of conversational implicature.

3. Test the applicability of Skopos Theory and its related rules to solve the problems of conversational implicatures texts when they are translated from English into Arabic.

4. Examine how far Grice's theory of Conversational Implicature and the Maxims governing them could solve the problem of implicature dilemma.

\section{The Methodology}

This study is concerned with the conversations between characters selected from the scripts of two English novels Lord of the Flies written by William Golding (1954) translated by Izzat Nassar (1991) and Nineteen Eighty-Four written by George Orwell, translated by Shafeeq AsaadFareed and Abdul Hameed Mahboob (1956) all of which are written in prose. Those conversations reflect different aspects of the real life as the maximal unit for the analysis.

Thus, the functional/Skopos (2008) Theory and Grice's Implicature Theory (1975) will be applied for data analysis to measure the accuracy of translating conversational implicature from English into Arabic. The assumption is that these two theories are appropriate to test and measure the accuracy of translations of such texts and may be generalized to other languages through their flexible rules and maxims. The study directs attention to different situations that embrace conversational implicatures among the characters and embody real life as chosen from two English novels and on play that have been translated into Arabic and reflect certain linguistic and pragmatic features to be analyzed separately by two distinctive approaches, namely, Skopos in 1980s to focus on the linguistic aspects at the macro and micro levels and Grice's approach to concentrate on the pragmatic aspects to understand what happened to the translated conversational implicatures.

With a view to analyze the data in a systematic, logical and sequent manner, the scripts have been first read and examined as a whole and then certain conversational implicatures are extracted as examples for the analysis. Those instances are categorized according to the problems embraced in their structures in accordance with the aims of this thesis.

Some practical steps are followed for the data analysis. First, the extracts are arranged in tables. Second, the Arabic words are transcribed into English according to the phonetic symbols in IPA (1975). Third, the Arabic texts are back translated literally into English. Four, a tentative model is created based on Grice's notion of the conversational implicature. A descriptive analysis is then conducted on the extracts according to Schjoldager's model (2008) while Baker's model (1998) of implicature is utilized for the pragmatic analysis at macro and micro level.

\subsection{Micro/Macro Analysis}

An awareness of micro- structure and macro-structure may be useful for the translators in their task of recognizing certain aspects of meaning. The detailed linguistic analysis of the texts is provided by microstructure analysis whereas the rhetorical aspects of the texts are provided by macrostructure analysis. In this study, however, the focus will be on both macrostructure and microstructure analysis.

In this respect, Nord (1997) states that the macrostructure is important as it structures a text into chapters, sections and paragraphs based on thematic configurations. She adds that text types have conventional macrostructures, which should be adapted to fit the target culture during translating.

In cases such as in translating conversational implicature, the macrostructure and rhetorical structure of the ST must be reconsidered in TT in which words and structure carrying similar implicature should be found. This is the way in which translators generally follow either intentionally or unintentionally in translating a text into another language, and this is expected to be confirmed from the analysis to be conducted in the present research.

In this study, the model of the macro analysis of the corpus that will be conducted is a model having been adopted from the work of Nord (1997). This type of analysis will help determine the kind of strategy that a translator follows in 
translating particular texts. While analyzing the data, Schjoldager's (2008) suggestions should be considered by a translator in answering the following questions:

- While translating, is the translator expected to focus on the form and content of the ST or on the effect of the TT?

- Is s/he expected to act as a communicator of somebody else's communication or as mediator between primary parties?

- Will his/her translation appear as an overt one or covert one?

Accordingly, if the translator concentrates on the form and content of the ST, acts as a communicator of somebody else's communication and produces an overt translation, s/he is choosing a ST-orientated translation. On the other hand, if the translator focuses on the effect of the TT, acts as a mediator between primary parties in a communication and produces a covert translation, s/he is choosing a TT-oriented translation.

The readers of the novels this study will include all kinds of people who can read. So, a translator is expected to communicate to them about what occurs between and among the characters in those novels. This means that $\mathrm{s} / \mathrm{he}$ needs to focus on the ST (semantic meaning), that her or his role is as a communicator of somebody else's communication, and produces an overt translation. Therefore, the translator chooses a source-text oriented macro-strategy.

Table 4.1 below displays an overview of the above-mentioned choices (Nord, 1997:68 cited in Schjoldager, 2008: drawn from Schjoldager, 2008, p. 92)

175).

Table 4.1 Macro-Analysis Taxonomy

\begin{tabular}{ll}
\hline Micro-strategy & Description \\
\hline Direct transfer & Transfer something unchanged. \\
Claque & $\begin{array}{l}\text { Transfer the structure or makes a very close translation (resulting in } \\
\text { unidiomatic language). }\end{array}$ \\
Direct translation & Translate in a word-or-word procedure (resulting in idiomatic language). \\
Oblique translation & Translate in sense-for-sense procedure. \\
Explication & Make implicit information explicit. \\
Paraphrase & Translate rather freely. \\
Condensation & Translate in a shorter way, which may involve implication. \\
& (Making explicit information implicit). \\
Adaptation & Re-create the effect, entirely or partially. \\
Addition & Add a unit of meaning \\
Substitution & Change the meaning. \\
Deletion & Leave out a unit of meaning. \\
Permutation & Translate in a different place. \\
\hline
\end{tabular}

Table 4.2 Micro-Analysis Taxonomy

\begin{tabular}{ll}
\hline Source -Text Oriented Macro-strategy & Target-Text Oriented Macro-strategy \\
\hline Focus on source -text form and content. & Focus on target-text effect. \\
Communication of somebody else's & Mediate between primary parties in a \\
communication. & communication. \\
Overt translation. & Covert translation. \\
\hline
\end{tabular}

\subsection{Taxonomy for Micro-Analysis}

Schjoldager (2008) proposes a model of translation procedures that is adopted for the microanalysis of this study. This model is made up of twelve translation procedures that are presented in Table 4.2 below. 
4.3 The Proposed Model of Pragmatic Analysis

In order to integrate the structure of the analysis, the third part of that analysis will be based on Grice's Implicature approach. This analysis examines the amount of appropriateness and suitability of Grice's approach, and its attendant maxims and the $\mathrm{CP}$ for the data employed in this work.

A tentative model with modifications based on Grice's general schema of the notion of conversational implicature is proposed here. The model will be in the form of general points and includes three measures. These are:

1. The first measure will focus on the reordering of the four maxims and reforming the sub maxims.

2. The second measure is concerned with the flouting of the maxims in conversational communication.

3. The third measure is undertaken to overcome problems in translating conversational implicature.

4.4 Reformulation of the Maxims

Apparently, some redundancy exists in Grice's formulation of the CP and its attendant maxims. Hence, a consideration of this redundancy is undertaken and tentative proposed model is formulated and adopted in this study as shown below:

Maxims of Quantity (Informativeness)

- Be informative

Maxim of Quality (Truthfulness)

- Do not say what is believed false or lacked of adequate evidence

Maxim of Relation (Relevance)

- Be relevant

- Be consistent and coherent

Maxim of Manner (Clarity)

- Be brief

- Be clearly expressed

I will use the symbol $(+>)$ to indicate the presence of implicature. Further, the analysis in this respect will be carried out on two levels namely, the macro and micro levels based on Baker's analysis of implicature (1998).

Consequently, the types of analysis and the translation approaches adopted and conducted in this study are presented in the diagrams below.

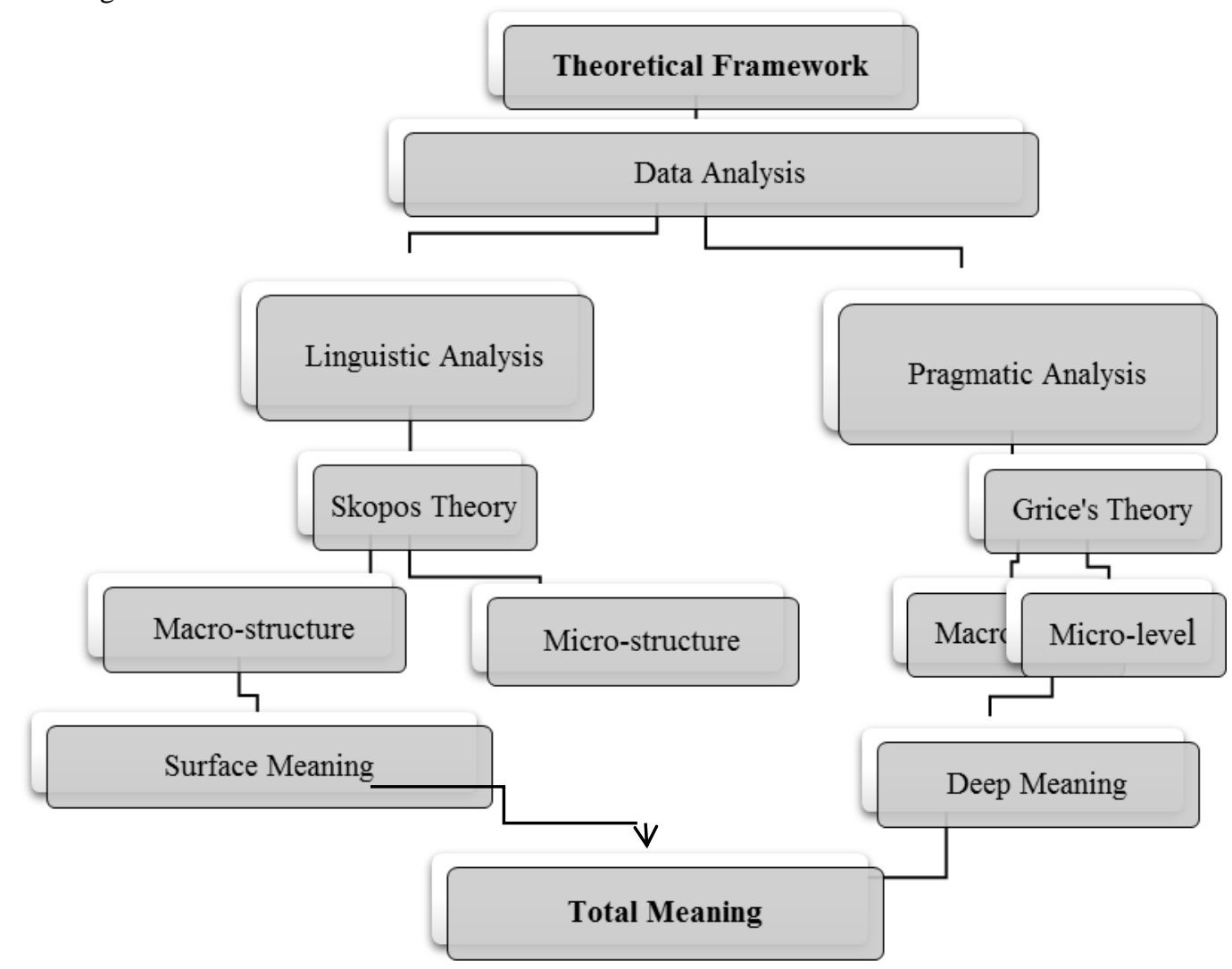

Figure 1. The framework of the data analysis 


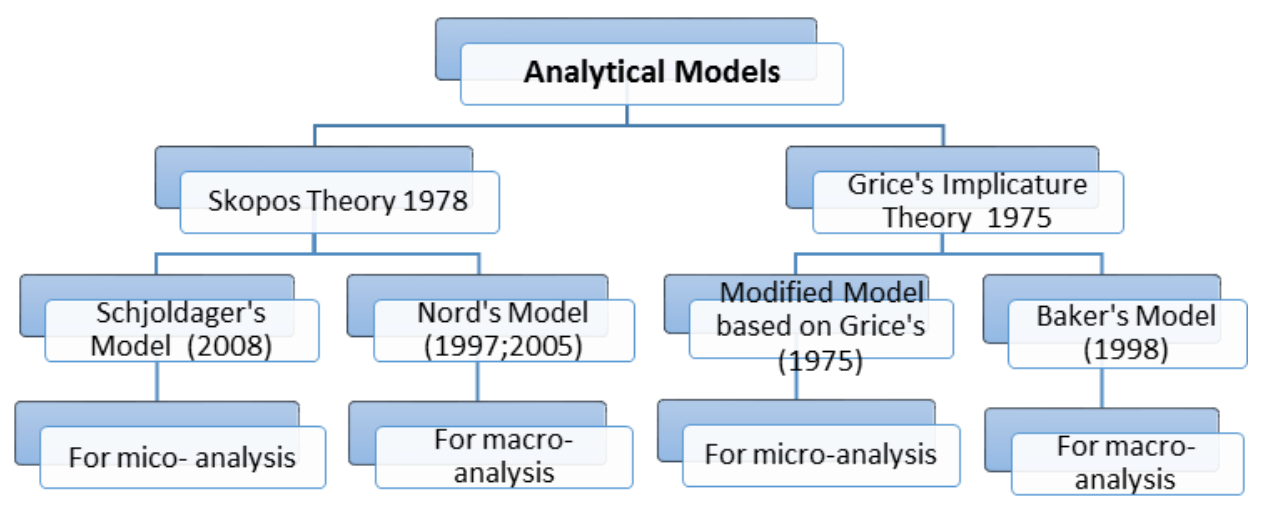

Figure 2. The Analytical Models

\section{Translation of Novels}

Much attention is given to poetry translation than to novel translation, Hu (2000). Moreover, Hu believes that the translation of novels is much more complicated than the translation of other literary genres as the translation of novels deals with bilingual, bi-cultural and bi-social transferences (Shen Dan (1995) cited in Hu 2000: 1). However, little material is available concerning the problems of translating novels and other literary works like plays. So far, less effort has been made in studying the specific problems of translating literary prose (Guessabi 2013:225). Furthermore, Bassnett points out that Hilaire Belloc sets general rules for translation of prose texts that cover both techniques and principles but not specifically novels (1998, 1991:109).

In the translation of novels, Bassnett $(1998,1991: 119)$ also touches upon the significance of "function", in which the translator must find the function of the SL text and render that function adequately in the TL text. Newmark (1988), adds that the translator of fiction can cover all the terms and expressions included in the novels and provide the cultural aspects. For example, puns or situations transcribe local expressions. Contrary to translating drama, there may be relative losses and gains in the translation of novels depending on a translator's assessments. In this respect, Newmark also argues that the translator of novels has to insert an alternative literary style into a different language culture.

\section{Data Analysis and Discussion}

This section examines extracted conversations to highlight some specific challenges and problems related to the translation of conversations. The tools of the Skopos and Grice approaches provide guidance to the analyses and discussions of the conversational situations.

Although there are some stylistic and linguistic translation problems for the selected data but this study focuses and discusses some rhetorical uses of the language such as tautology, irony, metaphor and euphemism that reflect cultural aspects of that language and constitute real obstacles in the translation of conversational implicature from English into Arabic.

\subsection{Tautology}

A tautology is saying the same thing again in a redundant and an uninformative way. Brown and Levinson (1983), state that tautology is the looking for informative out of the uninformative. Thus, the cited tautology expression "war is war" conveys meaning in a vague way. Thus, while the expression seems to be a needless repetition, the expression can be used more deeply to convey a significant communicative meaing, namely, that war connotes death, destruction, suffering, sadness, pain, and many bad things (Shehab, 2004, 695). However, it may also give the meaning of prosperity of trade, inflation, and black market for some people who are do their business the abnormal circumstances and reaping their wealth taking advantage of such hard times. Hence; this imposes the need for patience and open-mindedness when translating this aspect of language.

According to Grice (1975), tautologies trigger conversational implicature because they violate the Quantity maxim of a speaker's obligation to be as informative as is required for the purposes of the exchange (Shehab, 2004, 695). Thus, the tautological expressions a daughter is a daughter (?al ?ibnatu ?ibnatun الابنة ابنة) a father is a father (?al-?abu ?abun), and... because he's my son, because I'm his father and he's my son are all cases of conversational implicature arising from the speaker's violation of the maxim of Quantity.

In this respect, three approaches accounted for interpreting tautological utterances, namely: (1) the radical pragmatic approach, (2) the radical semantic approach and (3) the non-radical approach (cf. Wierzbicka 1987; see also Shehab, 2004, 695.).

In the radical pragmatic approach, universal principles of conversation govern the interpretation of tautological expression, and those expressions "are considered uninformative by themselves, but meaningful in context" (Okamoto 1993: 433-5). In contrast, the radical pragmatic approach argues interpreting tautological expressions is in part conversational and language-specific. Further, this approach maintains that the meaning of tautological utterances "cannot be fully predicted in terms of any universal pragmatic representation" (Shehab, 2004, 695). The non-radical approach, which is viewed as a compromise, argues interpreting tautological utterances combines semantics and pragmatics. Suppring this notion, Farghal (1992: 225) explains that tautological expressions have "instantaneous 
implicatures that are derivable only from the context of situation, and core implicatures that can be derived from semantic representations" (See also, Shehab, 2004, 696). Stressing the same point, Okamoto (1993: 434) maintains, that "given their core meanings, tautologies may convey additional meanings which are inferable pragmatically. Hence, the meanings of tautologies are best described in terms of both conversationally and pragmatic calculability". Consider the example below in Table 6.1:

Table 6.1 Example 1

\begin{tabular}{|c|c|}
\hline Golding 1954: 222 & Nassar 1991: 180 \\
\hline Source Text & Target Text \\
\hline (A) & بدأ الضابط مستاء مما يحدث فوق الجزيرة \\
\hline should have thought" said the officer as he & 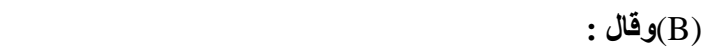 \\
\hline visualized the search before him, "I should & " يبدو لي مجموعة من الصبية البريطانيين - لانكم جميعا \\
\hline thought that a pace of British boys ... you're all & بريطانيون، اليس كذلك عليكم ان تتصرفوا بطريقة اكثر لياقة ، \\
\hline British aren't you? Would have been able to put & 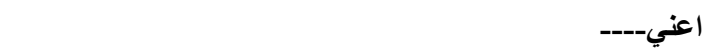 \\
\hline
\end{tabular}
officer said

(b) yabü lï majmü $\varepsilon$ min aŞŞbya ?abiriTänyün -

li?anakum jamïєan bariTnyüna, ?alaisa kaðälika

عalaikum ?an tataŞarafu bi Tarïqatin ?akeru

liyäqatin ?acnï .......

\section{Back Translation}

It seems to me a group of British boys - because you are all British, aren't you, you have to behave in a

more proper manner, I mean.......

As for the analysis of Example 1 at the macro level, the translator focuses on the form and content of the source text, and his role is only as a communicator for which he has produced an overt translation. Thus, he has chosen a source-text oriented macro strategy.

The translator also follows direct translation, word-for-word translation, which resulted in idiomatic language to translate this context into Arabic. He also transfers this situation without any change and he keeps the same structure in the target text. Accordingly, it is analyzed as a condensation micro -strategy.

The Skopos of this text failed to transfer the intended message to the target language because the intended meaning (the implicit meaning) is kept hidden between the lines.

From Grice's view at the macro level, the claim can be made that the additional meanings (implicatures) in this extract is not considered in the target language, as the speaker is not cooperative with the hearer in which the translator, intentionally or intentionally, does not infer the intended meaning beyond the semantic structure in the target text.

At the micro level, those utterances trigger conversational implicature via suspending the Quantity maxim, i.e., by violating the speaker's duty of being as less formative than required for the purpose of conversation. Moreover, this example falls within the partially context-dependent tautology.

Thus, the explicit argument can be made that tautologies generally seem to fall into two types depending upon context. These are: (1) partially context-dependent tautologies because their meanings are not entirely incidental to the context) and (2) completely context-dependent tautologies. The former type refers simply to tautologies that bear meanings when used in or out of context (Shehab, 2004). this tautological expression could have several possible interpretations, but when used in context their meanings are narrowed. In contrast, completely context-dependent tautologies refer to tautological expressions, bearing communicative import only when they are used in context. Besides, if the source language tautological expression is available in the target language, the translator renders that expression simply into the target language as a tautological expression. If it is unavailable in the target language, then the translator should try to render the implicit meaning of the tautological utterance without paying attention to the form of the source text.

\subsection{Metaphor}

This category is another clear case of the difference between the said and the unsaid meanings, in which one may utter something and mean something else. Some argue that the meaning of metaphor has to be made regardless of the linguistic surface structure of the metaphorical utterance (Stern, 2009). This, of course, creates situations in which the translator needs to exert much effort in order to arrive at the implicature intended by the use of a metaphor in a speech situation.

Grice (1975: 53) considers metaphor to be an approach of generating conversational implicature by violating the maxim of Quality. This violation arises when the speaker attempts to convey or stress a certain meaning in a strange and remarkable way. This fact underlies the contradiction of what is being proposed at face value once a metaphorical 
utterance is initiated. With respect to this, Searle (1979) says that metaphors show obvious untruth, semantic nonsense, or violations of conversational principles of communication (Shehab, 2004, 703).

Before discussing the data, pointing out that the translation of metaphor depends mostly on whether the metaphor is creatively used (an essential part of the text) or decoratively (just to add to the beauty of the text) (cf. Broeck 1981; see also Shehab, 2004, 703). If the metaphor is creative as often the case in a work of art, a formal equivalence is required though the formal equivalence occasionally renders the metaphor less natural to TL readers (Farghal and Shorafat 1996). If the metaphor is used decoratively as it sometimes is in editorials, a translator should practice flexibility in the sense that he can choose among formal, functional or ideational equivalence. That is, either the translates the metaphor creatively (formally) or renders meaning simply by reducing the metaphors to its communicative purpose. To illustrate, let us investigate the rendering of a metaphoric utterance by considering example 2 in Table 6.2 below.

Table 6.2 Example 2

\begin{tabular}{|c|c|}
\hline Orwell 1949: 225 & Fareed and Mahboob 1956: 239 \\
\hline Source Text & Target Text \\
\hline \multirow{3}{*}{$\begin{array}{l}\text { (A) Winston : You did it. You } \\
\text { reduce }+>\text { me to this. }\end{array}$} & 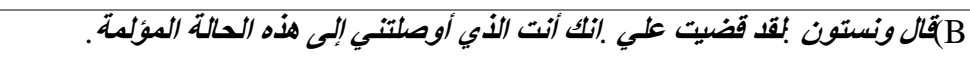 \\
\hline & (b) qäla Winston: laqadqadayta calyya. ?innaka ?anta ?allaðї \\
\hline & ?awŞaltanï ?ilä häðihi ?al-Hälati ?almu?limati. \\
\hline & Back Translation \\
\hline
\end{tabular}

In sentence 2 A above, you did it is rendered as لقد قضيت عليّ (you've just ruined me), in which the translator transfers the exact meaning of the sentence into the target text while he changes the structure of the phrase from the simple past in source text into perfect structure in the target text by preceding it with لقد (perfection indicator). In addition, the word "reduce" is used metaphorically in this situation because such a word is not normally used with human beings. However, the translation has been employed to weaken Winston and underestimate his human value. In this translation, Nassar makes the implicit meaning explicit, and, consequently, he transfers the source sense into the target text. Accordingly, he follows oblique translation micro strategy.

From perspective of Grice's principles, a sort of cooperation between the speaker and hearer of the Example 2 to enable the addressee catches the implicit meanings. Thus, the Cooperative Principles failed to observe the maxim of Quality, and thus, the speaker could not transfer the additional meaning to the hearer.

In the analysis of the above utterance, speaker flouts out the maxim of Quality, specifically, this utterance is used metaphorically, and it conveys implicit meaning that is different from the conventional meanings. Thus, a metaphorical meaning and a conversational implicature arise. Although this rendering is acceptable it does not consider the metaphorical meanings of the source utterance.

\subsection{Irony}

The interpretation of ironic utterances is greatly dependent on context as well as on various assumptions the speaker and addressee share. Mateo (1995: 172) writes "irony depends on context since it springs from the relationships of a word, expression or action with the whole text or situation". Thus, irony is not "something that can be recognized by a fixed set of linguistic or stylistic features: there is no recognizable ironic tone or style". This fact complicates the task of the translator when translating ironic utterances. What is possibly more important is that in the case of ironic utterances "what the speaker means is not identical with what the sentence means" (Searle 1979: 77). In other words, the speaker's communicative import and the sentence meaning are extremely at variance. Hence, the translator is usually faced with a double interpretation (the literal and the ironic). Then, he must choose between those two interpretations depending on three parameters that collectively activate the ironic situation: namely, speaker, addressee and the broader context (Shehab, 2004, 699). Norrick (1994: 411) notes that "irony requires that the recipient reject the literal meaning and infer something like its negation; allusion points beyond its surface meaning to some pre-existing text". However, Mateo (1995: 172-4) best describes the difficulty of translating irony as follows:

A conception of translation as a process of transporting "sense" does not account for the intricate process of humor translation since "sense" in humor, and particularly in irony, has a much more complex nature, which includes the speaker's intentions, the background knowledge of speaker and listener, the assumptions and presuppositions implicit in the text, the connotations of each word, etc.

Furthermore, what adds to the difficulty of translating irony is that "the ironist does not always need to signal his intention to ironize" (Ibid, 1995: 172-4). This is obvious in cases of implicit irony in which no indicators of irony are used. However, explicit irony, is highlighted by markers such as "it is ironic that, ironically, it would be a bitter irony if, there is a certain irony" (Barbe 1993: 579). The following utterance in Tables 6.3 illustrates this sort of communication: 
Table 6.3 Example 3

\begin{tabular}{|c|c|}
\hline Golding 1954: 197 & Nassar 1991: 129 \\
\hline Source Text & Target Text \\
\hline
\end{tabular}

(b) Ralph: ?unDrü ?iläðälika! ?atusammünatilka

?annära ?iŠäratan?

tilkanäruTabxinsata?kulüna

?al?änlanyabqäduxxänun. ?alätafhamüna ?

\begin{tabular}{l} 
Back Translation \\
\hline Ralph :Look at that !Do you call that fire a sign? It's a cooking fire you'll eat now there won't be \\
fire . Don't you understand?
\end{tabular}

In Example 3, Nassar's job is to help the readers understand the intended meaning. This means that he needs to focus on the effect of the target text, and he is a mediator between Ralph and the readers to transfer the implicit sarcastic sense of the source text. Thus, the translator chooses a target-text oriented macro strategy.

Nassar renders the above situation by resorting to different translation strategies: word-for-word translation to translate Look at that! While he changes the ironic sentence Call that a signal fire! to an imperative sentence by replacing the exclamation mark by a question mark; a whole sentence is added in which the translator re-creates partially the effect of the source text in the target text in which the translator uses the addition strategy to make the sense clearer for the readers. Newmark (1981), however, says that it is preferable, when translating ironic utterances, to use inverted commas or exclamation mark in order to alert to the ironic sense.

Hence, all the words in the italics as in Bare added to make more amplification in the target text and alteration of the exclamation mark into a question mark (A, in bold) also altered into rhetorical question to alert the reader that an ironic sense is intended in the original text (Shehab, 2004, 700; see also Le Gassick, 1975. Accordingly, this example should be analyzed as addition, explication and adaptation micro strategy. The Skopos of this text failed to transfer the intended message to the target language.

From Grice's point of view at the macro level, the participants in this situation apparently failed to observe the maxim of Quality meaning that neither the speaker nor the hearers are cooperative in this situation.

At the micro level, the speaker does not want to convey that the fire in question is a huge smoking fire that can be used as a signal to attract people's attention for saving them from their isolation in the island. The fire, however, is so small that cannot be used as a signal. By saying so, the speaker uses two methods to convey ironic meaning: first, using the exclamation mark as (Look at that!) and Call that a signal fire! Second, by using implicit meaning in the utterance That's a cooking fire, tilka näru Tabuxinto mean the fire is too small and could not be seen from a distance.

Thus, following Newmark's suggestion, the above utterance can be translated into something as:

Ralph: "?unDrü ?ilä ðälik! ?atusammüna tilka ?annara ?iŠäratun?

tilkanäruTabuxinsata?kulün?a?änlanyabqäduxxän.?alatafhamün?"

The English backtranslation: Ralph: Look at that! Do you call that fire a sign? It's a cooking fire you'll eat now there won't be fire. Don't you understand?

Nonetheless, in many instances of irony, literal translation does not account for the ironic meaning present in the original (See Shehab, 2004, p. 701 for other examines of a literal translation falling short.).

6.4 Proverbs

Proverbs are described as being lexically and syntactically inflexible, and they enjoy much stiffness and stability. This means that their linguistic components are not susceptible to any sort of addition, deletion, substitution or even modification. However, such dominantly linguistic phenomenon might have a function. It is probably used for the sake of being more effective, easily memorized or to have poetic touch. In this regard, Crystal (1980) states, "from a syntactic, it is seldom to find people using proverbs in their written, or rather printed works viewpoint, the words often do not permit the usual variability they display in other context". (See also Bolinger 1975 and Lyons 1969.)

Proverbs are mostly spoken rather than written expressions. Nevertheless, a they are used figuratively to give meaning to that which is said in way other than the usual meaning. Therefore, they are described as "conversational" (Norrick 1994). Truthfully, people are rarely found using proverbs in their written, or rather printed works, especially the scientific ones. This might be attributed to the fact that proverb utterances should be accompanied by certain implied gestures or harmonious intonations at the moment of speaking that increases their force, whereas this force can never be achieved by writing.

This is done either to suggest a picture in the mind's eye or to make a comparison. Proverbs embody imagery embedded in a simile, metaphor or metonymy (Zolfaghari \& Ameri, 2012, pp. 93-108). This characteristic arises essentially from 
the connection the speaker establishes between the abstract literal reading and the connotative proverbial interpretation. Consequently, one basic source of the language of figures of speech lies in proverbs, among others.

Proverbs may be divided into two types: cultural universal and cultural specific. The first type refers to those proverbs dealing with well-known ideas found in most cultures (Bahameed 2001). This type is proved to be translationally manageable because culturally universal types have a ready-made equivalent in the TL culture and could be rendered into the TL easily. Obviously, then, rendering the second type of proverbs is actually more difficult than the first. To illustrate the translation of proverbs, consider Example 4 below.

Table 6.4 Example 4

\begin{tabular}{|c|c|}
\hline Golding 1954: 143 & Nassar 1991: 165 \\
\hline Source Text & Target Text \\
\hline \multirow{2}{*}{ (A): the greatest ideas are the simplest+>. } & (B) خنوص :إن أعظم الأفكار ابسطها. \\
\hline & $\begin{array}{l}\text { (b) Piggy:?inna ?acDama ?al- ?afkäri } \\
\text { ?absaTuhä. }\end{array}$ \\
\hline \multicolumn{2}{|c|}{ Back Translation } \\
\hline
\end{tabular}

At the macro level, the translator focuses on the form and content of the source text, his role is as a communicator of Piggy's speech, and he produces an overt translation. Consequently, he chooses a source-text macro strategy.

At the micro level, the translator translates this example in word-for-word procedure resulting in idiomatic language. The structure of the target text is very close to that of the source text. Hence, it is analyzed as calque and a direct translation micro strategy.

The Skopos of this text is disabled for delivering the message of the ST to the target language as the implicit meaning is kept hidden between the lines.

From Grice's point of view at the macro level, Piggy is uncooperative with the hearer. Therefore, the hearer fails to receive the intended message. From Grice's point of view, at the macro level, the additional meanings (implicatures) in the above example are not considered in the target language because the speaker is uncooperative with the hearers.

At the micro level, the speaker violates the maxim of Quality because he provides less information than required to achieve good communication between the speaker and the hearer. (See Stanford Encyclopedia of Philosophy, 2014, for more of an explanation).

The second type of proverbs deals with culture specific that belongs to different communities within the same nation who use the same language such as those related to Arab countries. Translating of proverbs is, transnationally, more difficult in comparison with those that are culturally universal.

\subsection{Euphemisms}

Etymologically, the Greek euphemisms derived from euphemos ("auspicious, sounding good"), from eu+ pheme ("speech"), and from phania ("speak" (1681). A euphemism today is generally defined as "the use of a mild or indirect expression instead of one that is harsh or unpleasant direct" (The World Book Dictionary, 1979: 731). A euphemism is, therefore, substitutes an agreeable or inoffensive expression for one that is offensive or suggests something unpleasant (Qi, 2000, 135-141). The word also means the expression that substituted. In this respect, Linfoot-Ham (2005) states that euphemisms are of speakers' interest for three different reasons:

1. They make sense of word histories, for example, the English toilet derived from French toilettes ("towels") or the ancient Greek drakon ("snake"), or derived from present participle of derkomai ("see clearly").

2. They help us understand the concepts causing people psychological and social discomfort, e.g., Death: dearly departed, undertaker, obituary, pass away, no longer with us. Religion: Hebrew Ha-shim ("the name"), and English my lord ...etc. Sex anatomy: go out with, sleep with, make love with, etc. Money: well-off, comfortable, doing well, struggling to get by, etc. Mental and physical disability: visually impaired, physically challenged disabled, etc.

3. They provide us with people theories of the world, e.g., taboo: words have supernatural powers, as in the deity's name in Hebrew. Politeness: the demands of politeness place us in a double bind. On the one hand, we want to be friendly, and on the other hand, we do not want to be overbearing.

More comprehensively, Allan and Burridge (1991: 11-32) offer the following definition:

Euphemisms are alternatives to unpreferred expressions, and are used in order to avoid possible loss of face. The unpreferred expression may be taboo, fearsome, distasteful or for some other reason have too many negative connotations to felicitously execute speaker's communicative intention on a given occasion.

The above definition explicitly accounts for the politeness aspect of "face", which is basic to euphemism. The notion of face is a key to understanding the speaker's intentions and subsequently the lexical correlates in his expression. Thus, face is vital for choosing our utterances (Al-Shawi, 2013, 123-132). Understanding the intentions of this utterance is important because "what we say is likely to maintain, enhance, or damage our own face" (Allan and Burridge 1991: 5). The speaker's option for euphemism is basically meant to enhance his own face, that of audience, or of some third party by minimizing negative connotations or including positive ones. In his endeavor to avoid possible loss of face, a speaker may deviate from one or more of the maxims of conversation (Grice 1975).

Thus, breaking the maxims is partly face-oriented, or, as Brown and Levinson (1987: 95) put it: 
One powerful and pervasive motive for not talking Maxim-wise is the desire to give some attention to face. Politeness is then a major source of deviation from such rational efficiency and is communicated precisely by that deviation.

This shows that there is a close relationship between politeness principles (PP) and the maxims of conversation in the process of euphemizing. More specifically, (Farghal 1995: 4) maintains that "euphemisms are viewed as emanating not only from observing the (PP), but also from exploiting the maxims of conversation".

The politeness of euphemistic expressions is partly attributed to their indirectness (Brown and Levinson 1987). The argument has been made that politeness is the main motivation for people to use the strategy of indirectness and consequently become euphemistic. This being the case, euphemistic utterances would seem to be problematic in translation.

Using of euphemistic language reveals much about the relationship between the speaker and the addressee or some third party. This is true mainly because the speaker's option for euphemism is absolutely deliberate. For instance, a speaker may deliberately resort to using emotive euphemistic expressions in order to highlight the intended meaning to be conveyed through language.

To illustrate this case, consider the underlined English euphemistic expression in its context in Table 6.5 below.

Table 6.5 Example 5

\begin{tabular}{|c|c|}
\hline Orwell 1949: 12 & Fareed and Mahboob 1956: 205 \\
\hline Source Text & Target Text \\
\hline $\begin{array}{l}\text { (A) In the room over Mr. Charrington's } \\
\text { shop, when they could get there, Julia and }\end{array}$ & 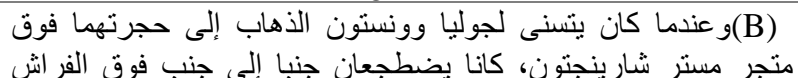 \\
\hline $\begin{array}{l}\text { Winston lay side by side on a stripped bed } \\
\text { under the open window, naked for the sake } \\
\text { of coolness. }\end{array}$ & 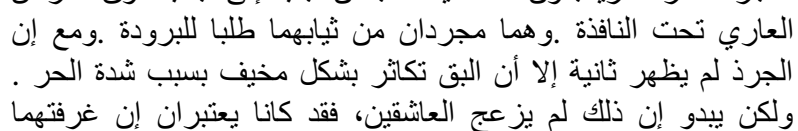 \\
\hline The rat had never come back, but bugs & فردوسا سواء أكانت قذرة أو نظيفة، وكانا يرشان الفلفل الأسود الناعم \\
\hline had+> Multiplied hideously in the heat. It & فوق كل شيء في الغرفة بمجرد وصولهما إليها .وكانا ييتاعان هذا الفلفل \\
\hline $\begin{array}{l}\text { did not seem to matter. Dirty or clean, the } \\
\text { room was paradise. As soon as they arrived }\end{array}$ & من جسديهما ثم بستسلمان للنود السود من من ثيابهما ويتو اصلان ,و العرق يتصبب \\
\hline
\end{tabular}
they would sprinkle everything with pepper (b) wacindamä käna yatasannä li Julia wa bought on the black market+>, tear off their Winston ?aððihäba ?ilä Hijratihimä fawqa majjari clothes and make love $+>$ with sweating bodies.

Mistar Chrrington, känä yadTajieäni janban ?ilä

Janbin fawqa ?alfiräŠi ?al cärï taHta ?annafiðati. Wahumä mujaradäni min Oiyabihimä Talaban lilburüdati. wamaca ?inna ?ajjirða lam yaDhar Oänyatan ?illa ?inna ?al baqqa takäӨara bi Šiklin Muxïfin bisababi Šidati ?al Har. Waläkin yabdü ?inna ðälika lam yuzєija ?alєäŠiqayni, faqad känä yactabiräni ?inna Gurfatahimä firdawsan sawä?a ?akänat qaðiratan ?aw naDïfatan, wakänä yaruŠäni ?al fulfula ?al?aswada ?annäcima fawqa kulli Šay?in? Fï ?al Gurfati bimujarradi wuŞülihimä ?ilayhä. Wakänä yabtäєäni häðä ?al fulfula mina ?al süqi ?al sawdä?i. Oumma yatajaradäni min Өiyäbihimä wayatawäŞaläni, wa ?al caraqu yataŞababu min jasadayhimä Oummayastaslimäni lilnawmi.

\section{Back Translation}

And when Julia and Winston had a chance to go to their room above Mr Charrington's shop, they would lie next to each other on the naked bed under the window. Naked from any clothes to cool down .Even though the rat never showed up again but the mosquitos horribly reproduced because of the heat .but that did not seem to worry the two lovers, and they thought of their room as heavens whether dirty or clean, and they were sprinkling black pepper powder all over the room as soon as they arrive .They use to buy that pepper from the black market.Then they would take their clothes off and continue ,while sweat comes out of their bodies and they fall asleep.

Obviously, this rendering does not work because it fails to account for the deliberate use of the euphemistic expression above by the "speaker". In addition, it does not reflect the euphemistic quality expressed in the original text. This means that Fareed and Mahboob focus on the effect of the target text, their role is a mediator between the narrator and the readers, and that they produce a covert translation. Consequently, they have chosen a target-text oriented macro strategy.

This translation, though euphemistic in Arabic, does not present the same level of euphemism as is presented in the source text. The translators are successful in their translation of this situation and convey the message in an acceptable way in, which they follow a word for word procedure to translate (make love) that results in a euphemistic language. 
Whereas, In the room over Mr. Charrington's shop is translated in a different place in the text. A unit of information is added at the end of the target text to give an obvious image about this critical situation and another one is deleted, word open is not existed in the target text. According to the above discussion, this example is analyzed as a direct translation, permutation and adaptation micro strategy.

The Skopos of this text failed to transfer the intended message to the target language because the intended meaning is kept hidden between the lines.

At the macro level, from Grice's point, the assumption could be made that both the speaker and the hearer may be intentionally uncooperative in indicating the additional meaning.

At the micro level, the translation preserves politeness via observing the (PP) and exploiting the (CP) specifically, violating the Quantity maxim by being less informative. However, euphemisms usually flout one or more of the maxims of conversation such as the Quantity, Quality and Manner, then giving rise to particularized implicatures. Consequently, flouting plays an important role in the use of euphemism.

To conclude, when it comes to translating euphemistic expressions, the following priorities should be borne in the translator's mind. First, the translator should seek to find a parallel euphemism in the target language that more or less retains the same euphemistic overtones of the original text. In this connection, Larson (1984: 116) confirmed that:

Euphemisms will often need to be translated by a comparable euphemism in the receptor Language.

The important thing is for the translator to recognize the euphemistic nature of the source language expression and then translate with an appropriate and acceptable expression of the receptor language whether euphemistic or not.

Second, if a parallel euphemism does not exist in the target language, the translator should convey the intended meaning but still preserve the euphemistic thrust of the original. Third, the translator should try to convey implied meaning without maintaining the euphemism of the original. In this case, he may refer to the use of neutral terms (AlShawi, 2013, 132). Finally, in some situations, an English euphemistic expression may be used where the same situations might not call for the use of euphemistic expressions in Arabic. For example, unlike the English culture, the Arabic culture euphemizes expressions having to do with drinking alcohol and getting drunk. This is because drinking alcohol is considered to be a bad habit, is highly condemned socially, and forbidden religiously. Thus, translators should be fully aware of this fact and other analogous cases in order to decide on the track they follow in translating euphemisms across cultures.

\section{Concluding Remarks}

The analysis and discussion of the Skopos and the Grice's implicature theories reveal that the translators encountered some challenging problems while translating the selected texts resulting from several reasons, including linguistic, social and cultural differences the between English and Arabic. To overcome these problems, the translators follow different methods and techniques to achieve consistent and coherent Arabic texts, equivalent to that of the original. The analyses also show that the translators follow different approaches such as source-text oriented and play a role as communicators or target-text oriented and plays the role of mediators. Furthermore, they implement several techniques in their translation; they mainly focus on the direct translation technique, and also resort to other methods such as claque, transliteration, paraphrasing, addition, adaptation, deletion and permutation at varying degrees. Most of the extracts are translated adequately enough. Although the translations fulfill the intended Skopos well, they may be inadequate in some situations at the micro level. Regarding the effectiveness and the success of Grice theory (the Maxims and the Cooperative Principle) the conversational implicature from English into Arabic. The analysis also reveals that all maxims are violated, but these violations do not result in breaking the Cooperative Principle. However, in all selected situations, the speakers mostly violate the maxim of Quality and the maxim Quantity comes in second place. Whereas, the maxims of Manner and Relevance are violated the least.

All in all, both the Skopos and Grice theories are successful and applicable at varying levels, in translating conversational implicature from English into Arabic. Nevertheless, Grice's approach is more successful in translating the conversational implicatures within the framework of this study. Accordingly, this study answers all the designed questions.

\section{References}

Allan, K., Burridge K., (1991). Euphemism and Dysphemism. Language Used as Shield and Weapon. Oxford/ New York: Oxford University Press.

Al-Shawi, M.A. (2015). Translating Conversational Implicature from English into Arabic, Ph.D thesis, Universiti Sains Malaysia USM, Penang, Malaysia.

Al-Shawi, M.A. (2013). Translating euphemisms: Theory and application. Journal of American Arabic Academy for Sciences and Technology, 8, 123-132.

Barnhart, C. (1979). The World Book Dictionary. Childcraft International Inc.Nord 2005

Baker M.Malmkjaer, K. (ed.) (1998/2001). Routledge encyclopedia of translation studies,London:Routledge.

Barbe, K. (1993). 'Isn't it ironic that ...: "Explicit irony"', Journal of Pragmatics, 6, pp. 579-590. 
Bassnett, S. (1998). 'The Translation Turn in Cultural Studies', in S. Bassnett and A. Lefevere, A. (eds.) Constructing cultures: Essays inliterary translation (pp. 123-140, Clevedon, United KingdomMultilingual Matters.

Bassnett, S. (1981). Translation Studies, $1^{\text {st }}$ edition, simultaneously published in the United States and Canada: Methuen \& Co. Ltd

Bolinger, D. L.and Sears, D.A. (1975). Aspects of language, $2^{\text {nd }}$ edition, New York: Harcourt, Brace, Jovanovich. Broeck, R. (1981). 'The limits of translating exemplified by metaphor translation', Poetics Today, 2(4), pp. 73-87.

Brown, P. and S. Levinson (1987). Politeness, Cambridge: Cambridge University Press.

Gazdar, G. (1979). Pragmatics: Implicature, presupposition, and logical form, New York: Academic.

Crystal, D.,(1980). Afirst dictionary of linguistics and phonetics, Boulder, CO: West view.

Farghal, M. (1992). Colloquial jordanian arabic tautologies.Journal of Pragmatics, 7(3), North-Holland.

Farghal,, M and Al-Shorafat, M.( 1996). The Translation of English Passives into Arabic: An Empirical Perspective. John Benjamins Publishing Company.

Grice, H. P. (1975). 'Logic and conversation', in Cole, P., and J.L. Morgan (eds.)Syntax and semantics, 3: Speech acts (pp. 41-58), New York: Academic Press. Available also on-line: www.utsc.utoronto.caolding, G. (1954) Lordof the Flies, London: Faber and Faber.

Guessabi, F. (2013). 'The culture in translating: Anovel from Arabic to English language, A case study: The Algerian novel',Arab World English Journal, 2, pp. 224-232.

Hu, Y. (2000). Tales of translation: Composing the new woman in China, 1898-1918, Palo Alto, CA:Stanford University Press.

IPA (1975). The undesirability of length marks in EFL phonemic transcription, Journal of the International Phonetic Association, vol. 43(2), 64-71.

Lyons, J. (1969). Introduction to theoretical linguistics, Cambridge: Cambridge University Press.

Larson, M. (1984) Meaning-based translation: A guide to cross-language equivalence, Lanham, MD: University Press of America.

Linfoot-Ham, K (2005). 'The linguistics of euphemism: A diachronic study of euphemism formation',Journal of Language and Linguistics, 4(2), pp. 227- 263.

Lyons, J. (1969). Introduction to theoretical linguistics, Cambridge: Cambridge University Press.

Mateo M., (1995). 'The Translation of irony', Translators' Journal, 40(1), pp. 171-178.

Newmark, P. (1981). Approaches to translation, Oxford: Pergamon Press Ltd.

Newmark, P. (1988). A textbook of translation, Hempstead, United Kingdom: Prentice Hall International.

Norrick, N., (1994). 'Involvement and joking in conversation'. Journal of Pragmatics, 22, 409-430.

Nord, C. (1997). Translating as a purposeful activity, Manchester: St. Jerome.

Okamoto, Sh. (1993). 'Nominal repetitive constructions in Japanese: The "tautology" controversy revisited', Journal of Pragmatics, vol. 20, pp. 433-466.

Ogden, C. K. and Richards, I. A. (1923). The meaning of meaning, $8^{\text {th }}$ edition, New York, Harcourt, Brace \& World, Inc.

Orwell, G. (1949). 1984, Orlando, FLA: Harcourt Brace Jovanovich Inc.

Qi, G. (2000). Cultural differences in Chinese and English euphemisms. Cross-Cultural Communication, 6(4), $135-141$.

Searle, J. (1979). Metaphor. In: Ortony, A. (ed.): Metaphor and Thought. First Ed., Cambridge: Cambridge University Press.

Stern, J. (2009). Metaphor and minimalism. Philos Stud DOI 10.1007/s11098-009-9486-3.from http://philosophy.uchicago.edu/faculty/files/stern/MetMinPhilSt09.pdf

Shehab, E. 2004). “The Translatability of utterances containing Implicatures from Arabic into English.” An-Najah Univ. J. Res. (H. Sc.),18(2), 2004. Retrieved from http://scholar.najah.edu/sites/default/files/journalarticle/translatability-utterances-containing-implicatures-\%E2\%80\%8E-arabic-english.pdf

Schjoldager, A. (2008). Translating and interpreting. Palto Alto, California: Academica.Press.

Vermeer, H. J. (2000). "Skopos and Commission in Translational Action." Translation Studies Reader. (2nd Edition). L. Venuti. New York: Routledge,

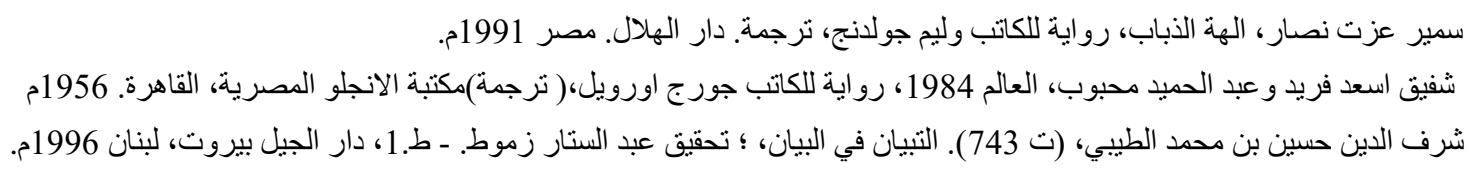

